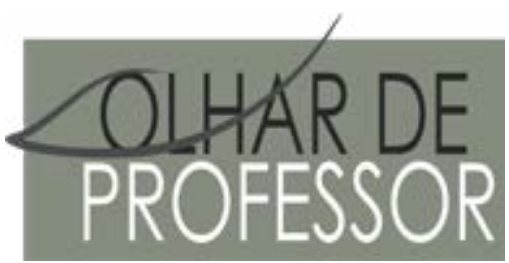

DOl: 10.5212/OLHARPROFR.v.22.0001

\title{
“OS SMURFS" ENCONTRAM MONET E OUTROS IMPRESSIONISTAS: ESTÁGIO DE DOCÊNCIA EM ARTES VISUAIS NA EDUCAÇÃO INFANTIL
}

\author{
“THE SMURFS" MEET MONET AND OTHER IMPRESSIONISTS: TEACHING INTERNSHIP IN VISUAL ARTS IN \\ EARLY CHILDHOOD EDUCATION
}

\section{“LOS PITUFOS” ENCUENTRAN A MONET Y OTROS IMPRESIONISTAS: LAS PRÁCTICAS DE LA ENSEÑANZA DE ARTES VISUALES EN LA EDUCACIÓN INICIAL}

\author{
JOÃO PAULO BALISCEI ${ }^{*}$ \\ JOSIMARI ZAGHETTI FABRI ${ }^{\star \star}$
}

\begin{abstract}
Resumo: É possível, no contexto escolar, trabalhar imagens do cotidiano infantil, relacionando-as com conhecimentos, artistas e movimentos específicos da História da Arte? Diante desse problema de pesquisa, objetivamos refletir sobre o Estágio de Docência em Artes Visuais na Educação Infantil e promover aproximações entre as imagens de personagens infantis e imagens da Arte. Para tanto, respaldamo-nos nos Estudos da Cultura Visual e analisamos as experiências vivenciadas junto a crianças com cinco anos de uma escola pública. Para as intervenções, elegemos a cor azul para aproximar "Os Smurfs" e obras e artistas impressionistas. As intervenções realizadas, assim como os diálogos estabelecidos na Universidade durante as orientações do Estágio de Docência, versam sobre a necessidade de problematizar estereótipos pictóricos e ampliar/diversificar as maneiras como as cores são utilizadas na Educação Infantil.
\end{abstract}

Palavras-chave: Estágio de docência. Ensino de Artes Visuais. Educação Infantil.

\begin{abstract}
Is it possible, in a scholastic context, to use images from children's daily life, relating them to specific knowledge, artists and movements in the Art History? Considering this research problem, we aim to reflect on the Teaching Internship in Visual Arts in Early Childhood Education and to promote approaches between the images of children's characters and images of Art. In order to do so, we based our research on Visual Culture Studies and analyze the experiences lived among five year old children from a public school. For the interventions, we chose the color blue as a bridge to "The Smurfs" and Impressionist works and artists. The accomplished interventions, as well as the dialogues established at the University during the Teaching Internship, address the need to problematize pictorial stereotypes and broaden/diversify how colors have been used in Early Childhood Education.
\end{abstract}

Keywords: Teaching internship; Teaching Visual Arts; Early Childhood Education.

Resumen: ¿Es posible, en el contexto escolar, trabajar imágenes del cotidiano infantil, relacionándolas con conocimientos, artistas y movimientos específicos de la Historia del Arte? Ante este problema de investigación, nos proponemos reflexionar sobre las Prácticas de la Enseñanza de Artes Visuales en la Educación Inicial y promover acercamientos entre las imágenes de personajes infantiles e imágenes del Arte. Para ello, nos apoyamos en los Estudios de la Cultura Visual y analizamos las experiencias vividas junto a niños de cinco años de una escuela pública. Para las intervenciones, elegimos el color azul para acercar a "Los Pitufos" y obras y artistas impresionistas. Las intervenciones realizadas, así como los diálogos establecidos en la Universidad durante las

\footnotetext{
* Doutor em Educação. Professor no curso de Artes Visuais e coordenador do Grupo de Pesquisa em Arte, Educação e Imagens - ARTEI. Universidade Estadual de Maringá. jpbaliscei@uem.br.

** Graduada em Artes Visuais. Universidade Estadual de Maringá. josimari@hotmail.com.
} 
orientaciones de Prácticas de la Enseñanza, versan sobre la necesidad de cuestionar estereotipos pictóricos y ampliar / diversificar las maneras como se utilizan los colores en la Educación Inicial.

Palabras clave: Prácticas Docentes; Enseñanza de Artes Visuales; Educación Infantil.

\section{CULTURA VISUAL E EDUCAÇÃO INFANTIL}

Em nível de graduação, muitos dos cursos de Artes Visuais ofertados por Instituições de Ensino Superior (IES) brasileiras habilitam acadêmicos(as) não só à pesquisa e produção artística, como também à licenciatura. Assim, são constituídos por disciplinas - reflexões, conceitos e teorias - voltadas para a prática de ensino de Artes Visuais e articulam-se para oportunizar aos(às) graduandos(as) vivências teórico-práticas em espaços educativos, tais como as escolas. Dentre essas disciplinas, neste artigo, damos tratamento especial àquelas que envolvem o Estágio de Docência em Artes Visuais já que, como argumenta Lampert (2005, p. 156) o “[...] estágio é a nossa primeira experiência concreta, quando acontecemos como professores”.

No curso de Artes Visuais ofertado pela Universidade Estadual de Maringá (UEM), curso e instituição onde desenvolvemos as atividades de ensino e pesquisa aqui relatadas, as disciplinas que envolvem a prática de estágio são concentradas no terceiro e quarto anos, como estabelece o Regulamento do Componente Estágio Curricular Supervisionado do curso de Artes Visuais (UEM, 2010). Esse documento estabelece que diversos locais são possíveis para atuação dos(as) estagiários(as), tanto espaços formais, como os escolares, quanto não escolares, como "[...] estabelecimentos de ensino público (preferencialmente) e privado, organizações não governamentais (ONGs), projetos sociais, escolas especializadas no ensino de artes visuais, empresas, [...] e museus” (UEM, 2010, p.25). A partir da diversidade de espaços educacionais os(as) profissionais em formação podem ampliar suas experiências, além de refletirem a respeito de metodologias de ensino, buscando adaptar os conteúdos trabalhados no curso de graduação ao local onde o estágio é desenvolvido.

Conforme o mesmo documento, ainda, o estágio é dividido em quatro disciplinas - Estágio Supervisionado em Artes Visuais I, II, III e IV - sendo elas voltadas para a prática de ensino de Artes Visuais na Educação Infantil, Ensino Fundamental, Ensino Médio e Educação Especial, respectivamente. Tendo participado de cada uma dessas disciplinas e buscado subsídios teórico-metodológicos para o ensino de Artes Visuais em variadas modalidades e níveis da Educação Básica, neste artigo, relatamos as práticas que realizamos junto às crianças da Educação Infantil. As práticas foram realizadas 2016, em um Centro Municipal de Educação Infantil público de Maringá/PR, com crianças de quatro e cinco anos.

Durante as observações - participações indiretas que ocorreram durante as aulas ministradas pela professora vigente da turma -, foram analisados aspectos pedagógicos, metodológicos e culturais que atravessam a formação artística das crianças da Educação Infantil. Já nas observações, identificamos nas visualidades do Centro de Educação Infantil referências a personagens de desenhos animados, extraídos da Cultura Visual e populares entre as crianças. As imagens desses personagens não eram apenas "trazidas" pelas crianças que exibiam seus materiais escolares estampados por representações do Mickey, Minnie, Hello Kitty, Super-heróis, Princesas e Fadas, por exemplo; como também "habitavam” os espaços, recursos didáticos e intervenções planejadas pelas docentes e demais profissionais da Educação Infantil.

Encontramos nesse exemplo, portanto, referências àquilo que Cunha (2014) denomina como "Cenários da Educação Infantil” - um coletivo de imagens que, segundo a autora, costuma ser utilizada pelas(os) docentes com finalidade de simples "embelezamento" do espaço, mas que também atua na significação dos corpos, comportamentos e identidades dos sujeitos infantis. Na perspectiva defendida pela autora, nos cenários instaurados na educação Infantil, personagens da Cultura Visual são aproximados de figuras totêmicas. Assim como as deusas e deuses representados nos totens, as múltiplas imagens de Mickey, Minnie, Princesas e Super-heróis são adoradas e reverenciadas pela simpatia que crianças e adultos são incentivados(as) a manifestar. Em sua atuação como pesquisadora e supervisora de estágio na Educação Infantil, Cunha (2014, p. 206) destaca: 
O que mais me surpreendia, e ainda surpreende, era o aspecto decorativo das escolas e, principalmente, das salas de aula, onde a maioria das crianças de zero a seis anos permanece em torno de 10 horas diárias. A impressão que tinha sobre as ambivalências escolares é de que elas funcionavam como uma espécie de cenografia natural da infância escolarizada, ou seja, há uma concepção sobre os modos de compor estes espaços que atravessa o tempo e os contextos socioculturais, tornando, assim, esses espaços como algo que naturalmente é assim.

Embora as referências a esses(as) personagens atuem como conteúdo de fácil aceitação pelas crianças - sendo esta a explicação utilizada pelas professoras para justificar a presença de tais imagens -, analisamos que as intervenções docentes que observamos apontaram para interpretações emitidas de um local comum, reforçando assim os estereótipos que essas visualidades propagam. As representações de corpo, de família, de infância, de raça e de sexualidade valorizadas pela Cultura Visual, tais como aquelas que exemplificamos anteriormente, não eram mencionadas e tampouco problematizadas pelas professoras da Educação Infantil, que a tratavam como neutras e "naturalmente” boas. Assim, encontramos no espaço da Educação Infantil indícios de que os cenários criados pelos(as) professores(as) simulam um outro mundo onde as diferenças culturais, étnicas, familiares, religiosas, sexuais e de classe não são representadas e onde os problemas reais são supostamente esquecidos. Nesses cenários, como analisa Cunha (2014, p. 210), as crianças e professores(as) não “[...] são mais negras, mas transformam-se em princesas louras, fadas aladas, Pokemóns, Teletubies. Não vivem em um buraco de barranco, mas numa floresta encantada, protegida pelas paredes escolares, pelos anões e pelos brincalhões dálmatas”.

O caráter contemplativo e reverenciador que os(as) professores(as) da Educação Infantil atribuíam à Cultura Visual pode ser aproximado à Abordagem da Satisfação, criticada por Hernández (2007). Nessa abordagem, conforme $\mathrm{o}$ autor, as imagens populares entre as crianças são consideradas pelas intervenções docentes, porém, não recebem um tratamento crítico ou problematizador e seus usos são justificados pelo prazer e satisfação que proporcionam aos(às) estudantes. Nesse ponto, também concordamos com o autor que seria inapropriado extinguir tais imagens dos contextos escolares e das intervenções docentes já que a Cultura Visual faz parte do cotidiano dos sujeitos contemporâneos e proporciona-lhes identificações, debates e conhecimentos. Por isso, argumentamos sobre a necessidade de professores(as) desenvolverem estratégias e metodologias mais abrangentes para o ensino de Artes Visuais tendo em vista as identidades e significados que são (des)autorizados pelas imagens que são selecionadas para integrar os espaços escolares. Hernández (2007, p. 67-68) explica que, quando “[...] os educadores não provocam os estudantes a prestar atenção às manifestações da cultura visual a partir de uma análise crítica, podem acabar validando esses prazeres e deixando de ajudá-los a construir ou melhorar sua autocrítica”.

Considerando as observações que fizemos no Centro Municipal de Educação Infantil, questionamo-nos, "é possível, no contexto escolar, trabalhar imagens do cotidiano infantil, relacionando-as com conhecimentos, artistas e movimentos específicos da História da Arte? Como desempenhar tratamentos diferentes daqueles que a Abordagem da Satisfação manifesta para com as imagens?”. Diante dessas perguntas, o objetivo deste artigo é refletir sobre o Estágio de Docência em Artes Visuais na Educação Infantil e promover aproximações entre as imagens de personagens infantis e imagens da Arte.

Tendo em vista a consideração de Oliveira (2005) de que há pouca produção científica que dialogue sobre o Estágio de Docência em Artes Visuais ou que ofereça relatos que possam ser compartilhados entre profissionais em formação, neste artigo, socializamos nossas vivências respaldando-as nos Estudos da Cultura Visual. Os Estudos da Cultura Visual atuam como um campo de investigação que, conforme explica Nunes (2010, p. 46) promove rupturas com epistemologias tradicionais acerca do ensino de Artes Visuais e "usa e problematiza as temáticas e os objetos do cotidiano, porque acredita que os sentidos atribuídos a esses não são únicos e sim mutáveis”. Assim, tendo conhecimento dos Estudos da Cultura Visual em nossas vivências com o estágio de Docência em Artes Visuais na Educação Infantil, sentimo-nos incentivados a pensar intervenções que aproximassem personagens infantis e imagens da Arte.

Assim, neste artigo relatamos nossas intervenções elaboradas a partir das relações que estabelecemos entre elementos visuais conhecidos pelas crianças e movimentos e artísticas reconhecidos pela História da Arte. Como sugere o título deste artigo, Os Smurfs - personagens azuis criados na década de 1950 pelo cartunista belga Pierre Culliford (1928-1992) - foram aproximados por nós das pinturas Impressionistas criadas pelo artista francês Claude Monet (1840-1926). A cor azul foi o eixo que escolhemos para estabelecer tal aproximação. 
Antes de descrever e analisar nossa intervenção, porém, pensando o Estágio de Docência como um momento para elaborar e aplicar propostas elaboradas durante a formação acadêmico-científica, optamos por ressaltar características da especificidade do estágio aplicado à licenciatura em Artes Visuais e as contribuições que ele confere para a construção da identidade docente.

\section{O ESTÁGIO DE DOCÊNCIA EM ARTES VISUAIS E O FAZER-SE PROFESSORLA]}

Quando exercidas em um curso de licenciatura, as atividades de estágio procuram atender objetivos que se articulem com os conteúdos, espaços e diretrizes escolares, tais como possibilitar a elaboração de considerações teóricas a respeito da vivência pedagógica e proporcionar experiências empíricas acerca das aptidões e condutas que envolvem a preparação do(a) estagiário(a) em formação como possível futuro(a) professor(a). Com a iminência do estágio e das atividades que ele prescreve, é comum que os(as) alunos(as) de licenciatura comecem a se perceber como professores(as). Passam a desenvolver características próprias à docência de modo intencional e questionam suas convicções à medida que se aproximam do(s) campo(s) de estágio.

É, também, durante o estágio que os(as) acadêmicos(as) de licenciatura podem revisitar os conteúdos, leituras e produções elaboradas em outras disciplinas e em anos anteriores para experimentá-los, de modo teórico e prático. Nesse sentido, concordamos com Oliveira (2005) ao argumentar que, diferente do que se pode pensar de início, o estágio não envolve apenas os(as) professores(as) a quem essa disciplina fora atribuída, mas também requer a participação dos(as) demais professores(as) de um curso de graduação, ainda que suas disciplinas e abordagens pouco tenham a ver com a licenciatura em si. O estágio evoca, portanto, conhecimentos, experiências e habilidades que foram desenvolvidas e acessadas também por outras disciplinas. No caso da graduação em Artes Visuais, podemos supor que o(a) docente responsável pelas disciplinas de História da Arte ou de Pintura, por exemplo, oferece aos(às) acadêmicos(as) conhecimentos históricos, artísticos, técnicos e expressivos que podem ser explorados nas práticas de estágio. A autora refere-se a esses saberes como “conhecimentos específicos” ou "saberes disciplinares"1 que, no estágio, são sobrepostos e combinados às políticas educacionais e às limitações e potencialidades de cada contexto. Logo, é possível inferir que o estágio aproxima os referenciais teóricos e habilidades técnicas desenvolvidos na academia com a docência e que, no caso das Artes Visuais, essa experiência não pode ser voltada apenas para o fazer artístico, mas precisa desenvolver meios para que esse fazer artístico possa ser ensinado e aprendido.

As assimetrias e conflitos entre os saberes e habilidades que a docência requer são ressaltados, sobretudo, se pensarmos na particularidade dos(as) acadêmicos(as) de Artes Visuais que, em muitos casos, costumam dar mais ênfase e demonstrar mais interesse em profissionalizar-se na prática de Artes Visuais do que na licenciatura, semelhante ao que expõe Lampert (2005, p. 151, grifos da autora).

Considerando os cursos de licenciatura que são sequenciais ao bacharelado em Artes Visuais, neste caso concreto, os acadêmicos ingressam na licenciatura com saberes específicos de artistas plásticos, para, então, articularem estes saberes com o saber da área de conhecimento do ensino da arte. Desta forma, torna-se evidente a dicotomia entre produzir arte e ensinar arte, entre o produtor de arte e o professor de arte (mediador entre arte e público). Embora deva haver uma co-relação entre o artista e o professor, o que acontece na prática educativa é a desconexão de ambas especificidades. Esses profissionais, por serem artistas-professores, acabam privilegiando, muitas vezes, o fazer artístico como atividade e não tratando as questões relativas ao ensino da área de seu conhecimento - arte e seus conteúdos.

Disso, é preciso sublinhar, primeiro, a necessidade de desenvolver saberes e habilidades ligados não só à criação artística como também ao ensino de Artes Visuais; e segundo, que as articulações pedagógicas de um(a) professor(a) também envolvem e requerem processos criativos - o que denota tomar

\footnotetext{
${ }^{1}$ Os saberes necessários à formação docente são ampliados por Lampert (2005) ao mencionar o Saber Disciplinar, Saber Curricular, Saber da Ciência da Educação, Saber da Tradição Pedagógica, Saber experiencial e Saber da Ação Pedagógica.
} 
o planejamento, o desenvolvimento de recursos didáticos e a elaboração de avaliação também como produções criativas e, quem sabe, artísticas.

Propomos, portanto, que o exercício de Estágio de Docência em Artes Visuais conecte identidades de produtores(as) de Arte e de professores(as) de Arte, sobrepondo e somando prática e teoria. Não obstante, segundo a autora, o(a) acadêmico(a) que já tem vivências na criação artística tende ao favorecimento do produto final, enquanto a docência requer a avaliação não do resultado, mas sim do processo de aprendizagem. É importante para o(a) estagiário(a) de Artes Visuais, assim, buscar certo equilíbrio entre sua prática artística e a vivência escolar, pois ambos colaborarão para o desenvolvimento de propostas educativas.

No que tange ao Estágio de Docência desenvolvido em espaços escolares, é comum que as representações idílicas e idealizadas que os(as) acadêmicos(as) tenham sobre a escola e sobre a educação sejam confrontadas com a realidade escolar. Oliveira (2005, p. 60) contribui para essa reflexão alegando que, por vezes, o(a) estagiário(a) sente-se assustado(a) pela rotina escolar, pelo autoritarismo que ela confere aos sujeitos e, ainda, "[...] por deparar-se com profissionais insatisfeitos, mal-humorados pela vida que levam, pelo trabalho que desenvolvem e pelo salário que recebem”. Nas observações que realizam no estágio, os(as) acadêmicos(as) também se deparam com metodologias tradicionais, atividades pouco atrativas e professores(as) que promovam saberes e conteúdos desconexos com aqueles que são abordados na academia.

No que tange à especificidade do ensino de Artes Visuais e às nossas experiências com o estágio de Docência na Educação Infantil, pudemos verificar que há, nas falas e posicionamentos dos(as) docentes, compreensões de "criatividade” e "fazer artístico" já superadas pelos estudos da área. Em outro estudo, Cunha (2017) denuncia que em muitas escolas de Educação Infantil o potencial criativo dos(as) alunos(as) ainda é considerado inato e espontâneo, como se, por serem crianças, fossem sujeitos dotados de uma espécie de "dom" para fazer Arte. Um dos riscos de perceber a criança como "naturalmente criativa” denota para o(a) professor(a), para a educação escolar e para o desenvolvimento do sujeito infantil, que suas produções permaneçam abandonadas a um "fazer livre” não orientado do qual procuramos nos afastar. Cunha (2017, p. 16) analisa que,

Na prática, professores acabam apenas disponibilizando materiais e fazendo algumas perguntas para que as crianças desenvolvam a sua dimensão criativa. Basear-se no pressuposto de que todas as crianças são potencialmente criativas induz à formulação de propostas pedagógicas com poucos desafios. Crianças, assim como adultos, precisam ser aguçadas, desafiadas, para serem ainda mais criativas.

Diante disso, é importante ressaltar que as observações realizadas nos campos de estágio não podem estar pautadas em pré-julgamentos e muito menos em observar os erros de profissionais com o intuito de apontar para as falhas dos métodos de ensino utilizados. Diante de situações avaliadas como inadequadas é necessário que o grupo, sob orientação de um(a) docente, dê menos ênfase ao suposto "erro" do(a) profissional e que relacione a situação com os textos e pesquisas lidas, buscando possíveis alternativas capazes de transpor a realidade e propor outras formas de exercitar a docência. É preciso aprender com o que já é ofertado no campo de estágio, mas também traçar e testar outros caminhos epistemológicos e metodológicos. Além disso, os(as) estagiários(as) podem contribuir compartilhando, inclusive com os(as) docentes em atuação, seus conhecimentos e habilidades, considerados por vezes, mais atuais, e motivando-os(as) à formação continuada e específica no que tange ao ensino de Artes Visuais.

Por essas peculiaridades, concordamos com Oliveira (2005) ao considerar o estágio como um espaço privilegiado de investigação e de questionamento, onde os(as) acadêmicos(as) são assistidos(as) e acompanhados(as) e os planos de aulas são elaborados coletivamente, sob a orientação de um(a) profissional. As observações, discussões, planos de aula, recursos didáticos, artigos e relatos oportunizadas pelo Estágio de Docência - assim como a socialização dessas produções - conferem aos(às) acadêmicos(as) condições para que tenham uma prática de estudo diferentes daquelas dos(as) profissionais que já passaram pela formação inicial. De modo semelhante, Lampert (2005) sublinha a importância que, no estágio de Docência em Artes Visuais, os(as) profissionais em formação não se acomodarem e subverterem o senso comum. 
Neste sentido, o estágio deve ser visto como uma dessas possibilidades, talvez a oportunidade única de abertura para uma prática pedagógica supervisionada/orientadas; o momento de colocar em prática um projeto de pesquisa cultivado e regado exaustivamente, discutido coletivamente, planejado aula-a-aula, contexto a contexto, trabalhando conteúdos articulados ao processo educacional relacionado ao ensino de arte. (LAMPERT, 2005, p. 153-154).

A autora não só revela o cuidado e a dedicação que o Estágio de Docência pode atribuir às práticas tidas como corriqueiras ao(à) profissional já formado(a) - como a elaboração de planos de aula - como chama atenção para a ação do(a) orientador(a) do estágio ao acompanhar e atender os(as) envolvidos(as). Mais do que uma atividade técnica e distanciada, o Estágio de Docência envolve sujeitos que, quiçá, compartilharão da mesma profissão e, neste sentido, podem compartilhar afetos, angústias, expectativas, dificuldades, realizações e projetos. Envolvem-se na (trans)formação de suas identidades docentes; essa trata-se de uma "identidade de projeto" que modifica-se (adapta-se, expande-se, fortalece-se) conforme as experiências a ela acrescentada. Oliveira (2005, p. 63) explica que na "[...] identidade docente estão presentes os conceitos, as relações que o professor estabelece com sua área de conhecimento, sua leitura de mundo, sua ética profissional e o valor que dá a sua profissão”.

Nossas primeiras experiências com o Estágio de Docência em Artes Visuais, assim, contribuíram para a formação e transformação de nossa identidade docente, à medida que fomos confrontados com a realidade escolar dos sujeitos infantis, com as curiosidades e interesses que demonstravam pelo conhecimento artístico e com a necessidade de selecionar um conteúdo-tema para o desenvolvimento de nossas regências. Na ocasião, partimos da cor azul como eixo de possível aproximação entre as imagens já conhecidas pelas crianças e as imagens da Arte que pretendíamos apresentar a elas. O azul e os recursos e ações pedagógicas que desenvolvemos, oportunizaram, portanto, que Os Smurfs e o Impressionismo fossem significados por crianças de quatro e cinco ano de um Centro Municipal de Educação Infantil de Maringá, Paraná2, em 2016.

\section{O AZUL DE “OS SMURFS”E O AZUL DO IMPRESSIONISMO}

Como primeira experiência no espaço escolar com crianças de quatro e cinco anos de idade, pautamos nossas regências em atividades voltadas às imagens do universo infantil, como uma porta de entrada às imagens da Arte, especificamente do movimento Impressionista. Na primeira regência, portanto, analisamos com as crianças as características visuais dos personagens de Os Smurfs e além disso debatemos sobre suas configurações familiares.

Os Smurfs foram criados na década de 1950 pelo cartunista belga Pierre Culliford, mais conhecido como Peyo. Inicialmente, esses personagens apareceram como coadjuvantes em histórias em quadrinhos e, mediante a aceitação do público, tornaram-se protagonistas de uma animação na década de 1980. Eles são pequenas criaturas azuis que vivem isolados em uma floresta, e que são nomeados de acordo com sua personalidade e funções. Papai Smurf, por exemplo, é o chefe da vila e um dos principais personagens, enquanto Gargamel é o antagonista da história. Outros personagens são Gênio, Desastrado, Fazendeiro, Harmonia, Smurfette, Vaidoso e Valente - esses dois últimos foram destacados por nós na Figura 1. Os conflitos versam sobre o cotidiano dos personagens, com características de aventura, comédia e elementos do universo fantástico.

\footnotetext{
${ }^{2}$ As regências foram divididas em dois períodos matutinos de aproximadamente duas horas e meia cada. Os planos de aula foram elaborados de forma contínua, em que as atividades da segunda regência seguiriam a temática da primeira.
} 


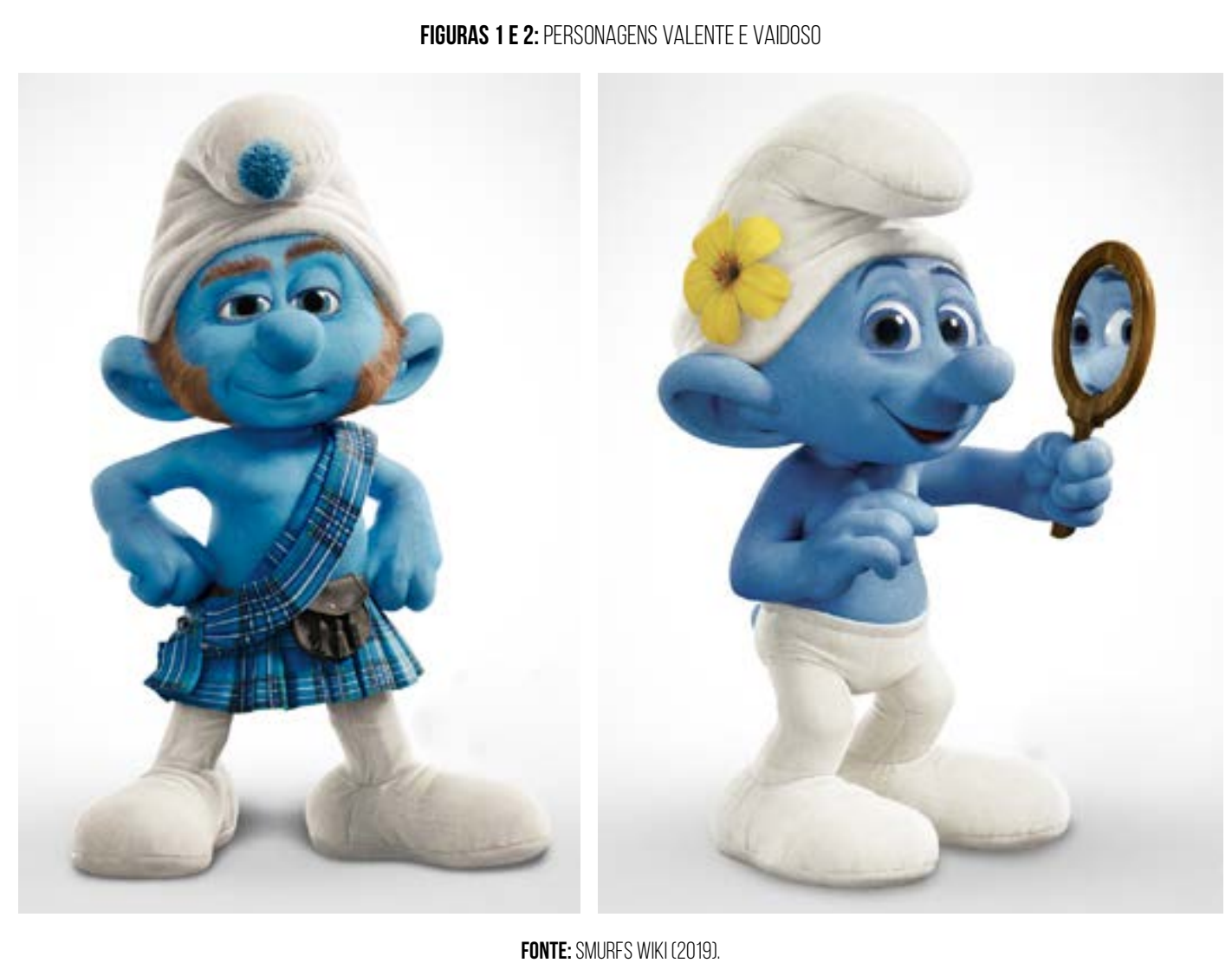

Atualmente, a popularidade de Os Smurfs pode ser atribuída a uma série de brinquedos, roupas, parques temáticos e produtos alimentícios relacionados à marca, assim como ao lançamento de filmes de longa-metragem intitulados Os Smurfs (2011) e Os Smurfs 2 (2013) e Os Smurfs e a Vila Perdida (2017). Por serem conhecidos há muito tempo e pelo lançamento dos filmes de longa-metragem mencionados, consideramos Os Smurfs uma boa opção para mesclar as imagens do dia a dia das crianças com os conteúdos específicos das Artes Visuais. Além disso, avaliamos que a cor azul empregada na pele desses personagens é uma característica que os difere das outras imagens que têm sido mostradas na Educação Infantil, e por isso, distancia-se de representações estereotipadas e convencionais.

O Impressionismo, por sua vez, trata-se de um movimento artístico de origem francesa do século XIX, que possibilitou uma nova forma de retratar a natureza utilizando pinceladas soltas e dando ênfase na luz e no movimento. O termo "impressionismo" foi utilizado pela primeira vez na História da Arte em 1874, quando, conforme explicam Bolloch et al. (2012), um jornalista, em tom de ironia, zombou de uma exposição que reunira obras de 35 artistas. "Uma vez que estou impressionado, deve haver impressão ali" (BOLLOCH et al., 2012) debochou o jornalista se referindo à pintura Impressão, sol nascente (1872) de Claude Monet. A partir daí, o termo Impressionismo (originalmente utilizado de forma pejorativa) foi ressignificado e defendido por um grupo de artistas que compartilhavam de interesses plásticos semelhantes. Além de Monet, Pierre-Auguste Renoir, Mary Cassatt e Berthe Morisot transgrediram a norma até então instaurada por outros(as) artistas. Os(as) impressionistas objetivaram materializar plasticamente as suas primeiras impressões, registrando, com certa rapidez, as sensações imediatas da luz e da cor. Nesse processo, muitos(as) deixaram de elaborar esboços preliminares e se recusaram a pintar dentro de seus ateliês e passaram a pintar ao ar livre. Na Figura 3, nota-se que o céu e a água foram representados em tons azulados e com pinceladas rápidas que enfatizam a luz no momento exato que Monet pintara essa composição, que sugere tratar de um dia ensolarado. 


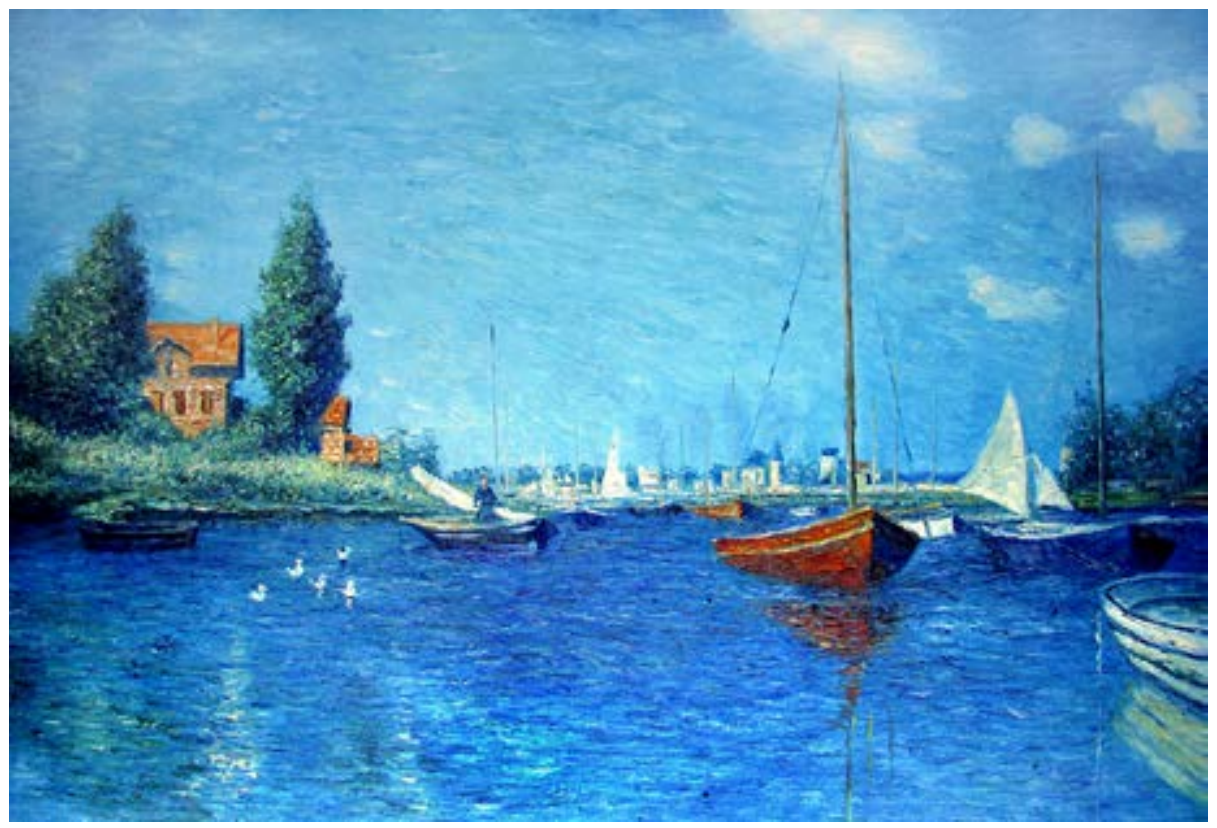

FONTE: WIIIART (2019)

Para aproximar a cultura infantil das produções dos(as) artistas impressionistas, na primeira regência propusemos leituras e debates em torno de imagens de Os Smurfs dando ênfase à cor azul, como elemento formal, já que ambas as imagens têm como característica o uso da cor azul - como pode ser percebido se aproximarmos as Figuras 1, 2 e 3. Para tanto, imprimimos e plastificamos imagens de seis personagens em um suporte de papel tamanho A5: Papai Smurf, Smurfette, Valente, Desastrado, Gênio e Vaidoso. O cuidado a partir do qual tais recursos foram elaborados possibilitou que as crianças os manuseassem sem dificuldades e que se interessassem pelos conteúdos visualmente apresentados.

Compreendendo a leitura de imagens como uma atividade intrínseca ao ensino de Artes Visuais, chamamos atenção para os personagens impressos, individualmente, instigando as crianças para que identificassem e mencionassem suas características físicas e psicológicas. Em seguida, colamos as imagens lado a lado, na lousa a fim que os(as) alunos(as) percebessem as semelhanças e diferenças entre eles. Expor as imagens coletivamente foi importante para que as crianças reconhecessem que os corpos dos personagens eram coloridos em uma tonalidade específica de azul e que isso os tornava diferentes de nós. Perceberam também que as roupas e acessórios usados pelos personagens não tinham o tom azulado de seus corpos. Pela semelhança física entre tais personagens, as crianças rapidamente os identificaram como sendo uma família e nesse ponto nós chamamos atenção para as diferentes configurações que os agrupamentos familiares poderiam assumir. Com isso, verificamos que uma leitura de imagem respaldada nos Estudos da Cultura Visual transcendem os aspectos formais e estéticos de um artefato e propõem reflexões mais amplas, como explica Sardelich (2006). Conforme explica a autora a proposta da Cultura Visual "[...] enfatiza que o campo de estudos não se organiza a partir de nomes de artefatos, fatos e ou sujeitos, mas sim de seus significados culturais, vinculando-se à noção de mediação de representações, valores e identidades” (SARDELICH, 2006, p. 466). Além da configuração familiar, gênero e corpo, outros atravessamentos identitários foram contemplados na leitura de imagem que realizamos com as crianças.

Por exemplo, diante das figuras de Valente e Vaidoso - personagens masculinos representados com saia e com uma flor e espelho, respectivamente, conforme destacamos nas Figuras 1 e 2 - as crianças questionaram-nos se os meninos poderiam usar adereços que, socialmente, têm sido atribuídos às mulheres e à feminilidade. $\mathrm{O}$ estranhamento expressado pelas crianças frente a personagens masculinos que borram as fronteiras socialmente estabelecidas para cada gênero vai ao encontro da constatação de Nunes e Martins (2017), de que os meninos sentem medo de serem identificados como femininos - daí o repúdio que manifestam pelos movimentos, sons, roupas, brinquedos e imagens utilizadas pelas meninas. Sobre isso, Nunes e Martins (2017, p. 103) afirmam que nas instituições escolares, de maneiras veladas 
e explícitas, os meninos aprendem que “[...] podem ser ofendidos se expressarem ligação ou preferência por artefatos considerados do mundo feminino. Aprendem, também, a criar estratégias de combate a qualquer comparação com as meninas”. Nesse sentido, concordamos com a autora e com o autor sobre a importância da mediação docente ao propor atividades e reflexões que levem ao questionamento e à problematização das normativas que envolvem identidades culturais, tais como gênero.

Diante dessa ênfase dada ao corpo de Os Smurfs durante a leitura de imagens, propusemos às crianças uma atividade corporal, oralmente direcionada, a partir da qual elas puderam reconhecer e nomear as partes e estruturas de seus corpos e identificar diferenças e semelhanças entre si. Pedimos que tocassem e sentissem a cabeça, o tronco, os braços e as pernas, percebendo em que região estavam e quais eram os pontos de ligamento entre uma parte e outra. Consideramos que essa etapa de reconhecimento do esquema corporal foi importante para o desenvolvimento da atividade seguinte em que solicitamos às crianças que desenhassem suas famílias. As composições foram feitas em papel branco e com giz de cera. Em referência aos personagens de Os Smurfs, os(as) alunos(as) foram orientados(as) a utilizarem gizes azuis para representar as partes dos corpos de seus e suas familiares, como pode ser examinado em um dos desenhos feitos pelas crianças (Figura 4).

FIGURA 4: FAMILIA DE ALUNA DA EDUCAÇÃO INFANTIL.

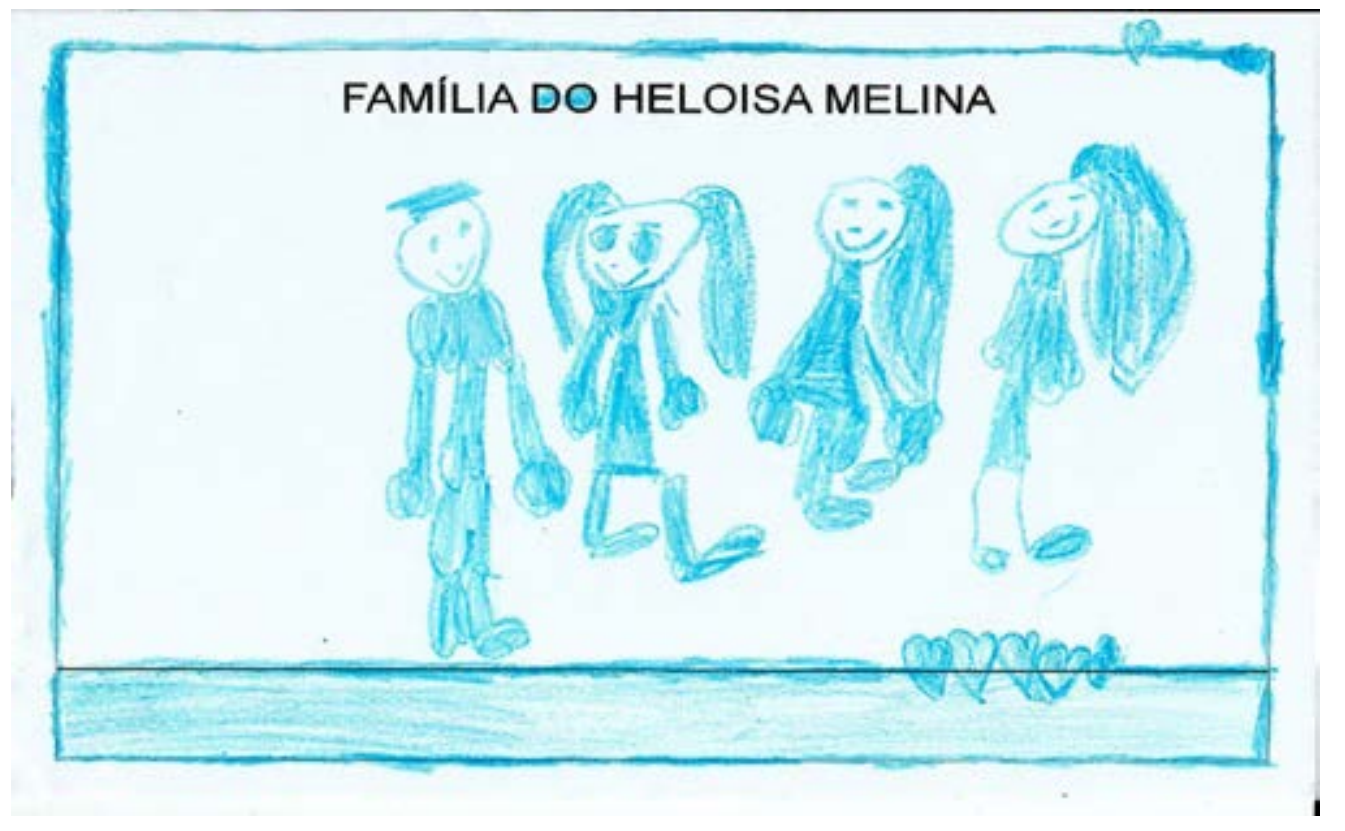

FONTE: ARQUIVO PESSOAL, २016.

Nesse desenho em questão, uma aluna de cinco anos utilizou um mesmo giz de cera azul para representar os e as membros de sua família. Apesar de durante a explicação da atividade termos sugerido que roupas e objetos pessoais dos familiares fossem caracterizados com outras cores - assim como sãos as roupas e objetos de Os Smurfs, as crianças acabaram desenhando tudo com o giz de cera azul. Não fizemos nenhuma objeção quanto à mudança uma vez que a consideramos interessante para o desenvolvimento da proposta de tematizar a cor azul.

Ao final dessa atividade de desenho, entregamos para cada aluno(a) uma folha impressa com os personagens de Os Smurfs apresentados anteriormente. Na ocasião pedimos para que as crianças circulassem os personagens cujos corpos não fossem coloridos de azul. Também pedimos que contassem a quantidade de personagens azuis e que anotassem na parte inferior do papel. Antes de encerrar a aula, retomamos os desenhos feitos com a temática de família e conversamos com as crianças pedindo que nos contassem quem eram e que explicassem os motivos de os (as) terem desenhado com suas respectivas características. 


\section{A FUGA DOS LÁPIS AZUIS}

Na segunda regência, seguimos com a temática da cor azul e aproximamos os personagens de Os Smurfs com as produções impressionistas. O azul presente na pele dos(as) personagens de Os Smurfs e utilizado pelos(as) impressionistas para colorir o céu. Desta forma, as imagens contemporâneas do universo infantil foram aproximadas de imagens da Arte reconhecidas e valorizadas historicamente. Nessa segunda regência, inicialmente compartilhamos com as crianças três obras Impressionistas: Barcos vermelhos, Angeteuil (1875) - representada na Figura 3 - e Caminhada no penhasco Pourville (1882), ambas de Claude Monet; e O Sena em Bercy (1876-78), de Paul Cézanne, conforme disposto na Figura 4. Em comum, as obras dos pintores franceses têm a temática de paisagem, as pinceladas rápidas e perceptíveis, a mistura de cores no próprio suporte e - o mais importante para essa intervenção em específico - o emprego de tons de azul para colorir o céu e a água.

\section{FIGURAS 5 E 6: CAMINHADA NO PENHASCO POURVILLE(1882], DE CLAUDE MONET; E O SENA EM BERCY(1876-78), DE PAUL CÉZANNE.}
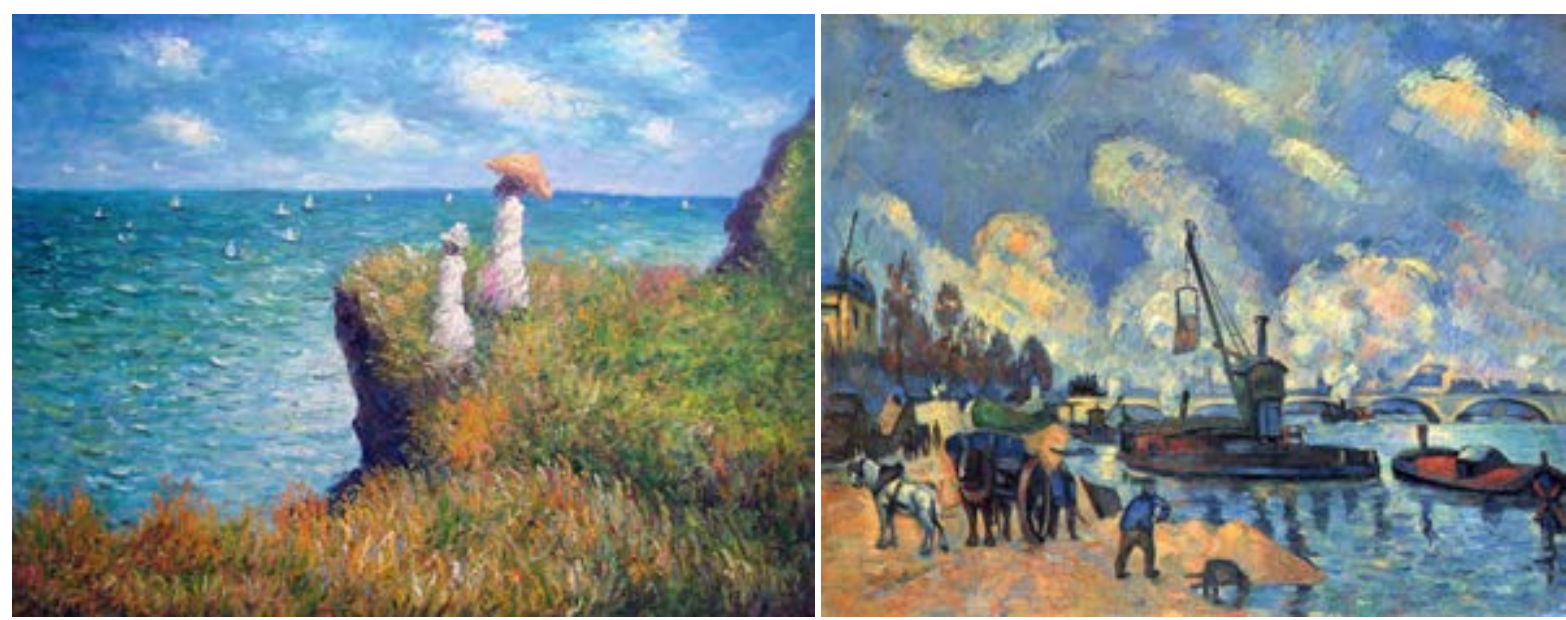

FONTE: PORTAL DE ARTE (2019); ARTE FAMOSO (2019)

Destacamos com as crianças a cor azul nas imagens, presente no céu e no mar e propusemos que elas realizassem desenhos com base nas paisagens retratadas pelos Impressionistas. A proposta de realizar desenhos tendo produções artísticas como referências harmoniza-se com a reflexão feita por Iavelberg (2013, p. 16) de que a autoria de um desenho "[...] não se perde quando o desenhista dialoga com o desenho de outros, sejam artistas, sejam crianças". Consideramos que os desenhos feitos pelas crianças de quatro e cinco anos da turma em que realizamos o Estágio de Docência em Artes Visuais expressavam características da fase que a autora denomina como "Desenho de Apropriação". Essa fase do desenho infantil é caracterizada pela representação de elementos presentes no contexto em que a criança está inserida, demonstrando interesse e capacidade de desenhar referências da realidade. Nas palavras de Iavelberg (2013, p. 26-27), nessa fase, a criança “[...] quer ter domínios de representação do espaço, construção de fórmulas e composição, aproximação de modelos de imagens existentes”. Com base nisso e nos desenhos que as crianças fizeram em outras aulas observadas por nós, avaliamos que elas possuíam condições cognitivas e expressivas para realizar desenhos tendo as obras impressionistas como referência.

Para a realização do desenho, orientamos que buscassem seus estojos de lápis de cor, guardados em uma caixa coletiva no armário da sala. Para a surpresa das crianças, porém, nos estojos não havia nenhum lápis de cor de tom azul. Todas as outras cores estavam lá. O que aconteceu com os lápis azuis? Foram roubados? Fugiram? Como estratégia de investimento e ludicidade na história que denominamos de “A fuga dos lápis azuis”3, nós retiramos todos os lápis azuis dos estojos das crianças e deixamos, na caixa coletiva, uma carta supostamente deixada pelos lápis fugitivos avisando às crianças sobre o seu sumiço. Avaliamos que nossas ações em retirar os lápis azuis e simular a fuga deles por meio da brincadeira dialoga

\footnotetext{
${ }^{3}$ Essa história foi motivada pela leitura da literatura infantil $O$ dia em que os lápis desistiram (2013), do escritor estadunidense Drew Daywalt.
} 
com a Base Nacional Comum Curricular - BNCC (BRASIL, 2018, p.38, grifos do autor) quando reitera “[...] a necessidade de imprimir intencionalidade educativa às práticas pedagógicas na Educação Infantil”.

Como em uma brincadeira de faz de conta, a carta escrita por nós e supostamente deixada pelos lápis azuis comunicava às crianças: "Nós, lápis azuis, estamos tristes! Na maioria das vezes, somos usados para pintar céu e mar. Por esta razão, fugimos. Agora, vocês terão que usar outras cores para pintar. Deixamos alguns exemplos de obra de arte! Até mais, amigos!”.

A insatisfação supostamente manifestada pelos lápis azuis por serem utilizados, na maior parte das vezes, para colorir céu e água, na verdade, era nossa. Durante as observações realizadas como etapa obrigatória do Estágio de Docência em Artes Visuais percebemos que não só as crianças, mas também os(as) professores(as) da Educação Infantil faziam uso convencional e estereotipado das cores. Nessa lógica de raciocínio, o sol era colorido de amarelo, as copas das árvores de verde, as maçãs e corações de vermelho, e o céu, como destacamos, de azul ${ }^{4}$.

A estereotipia - que originalmente esteve relacionada a um processo de impressão e reprodução de imagens, como explica Rauen (2010) - fora apropriada pelos espaços escolares de maneira negativa, a partir de tecnologias como o mimeógrafo e as impressoras que originam desenhos repetitivos, com traços econômicos e com uma estética infantilizada, avaliada pela autora como vulgar e de baixa qualidade. A partir dessa conceituação e das observações que fizemos, consideramos que no Centro Municipal de educação Infantil onde desenvolvemos o Estágio de Docência em Artes Visuais, não só os desenhos eram estereotipados, mas também o uso das cores.

Concordamos com Iavelberg (2013) que a Educação Infantil oferece significativa contribuição para que as crianças aprendam a identificar, nomear, gostar (ou não gostar) e utilizar as cores de maneiras específicas. Os(As) alunos(as) podem, como explica a autora, preservar as cores da realidade e também subvertê-las, conforme os incentivos, repreensões e orientações do(a) discente e conforme as referências visuais que lhes são apresentadas. Pensando nisso, mostramos às crianças outras três obras impressionistas, todas elas também de paisagens e compostas com características do estilo artístico, porém com céus coloridos com outras cores que não o azul. Veneza ao pôr do sol (1908-12), de Claude Monet; Pendurando a roupa para secar (1875), de Berthe Morisot; e Paisagem (1885), de Pierre-Auguste Renoir são obras impressionistas que, como evidenciamos nas Figuras 5 e 6, apresentam céus com tons amarelados, alaranjados, rosados e acinzentados.

FIGURAS 7, 8 E 9: VENEZA AO PÔR DO SOL (1908-12), DE CLAUDE MONET; PENDURANDO A ROUPA PARA SECAR(1875), DE BERTHE MORISOT.
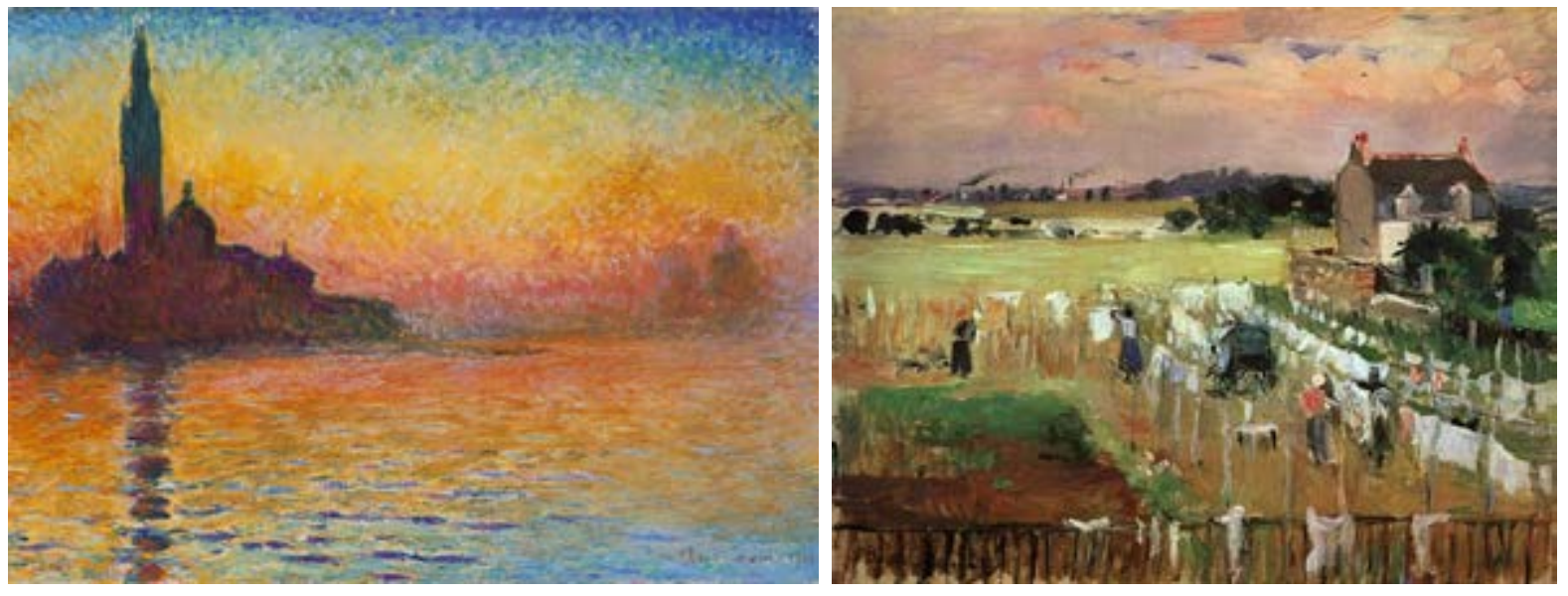

FONTE: 360 MERIDIANOS (2019); ARTVALUE (2019)

\footnotetext{
${ }^{4}$ Interessante observar que, conforme Pastoureau e Simonnet (2006) as pinturas, gravuras, tecelagens e demais expressões das Artes Visuais, passaram a representar os céus com tons azulados apenas no século XII, em referência ao Deus cristão que, à época, passou a ser concebido como um ser de luz. Até então, conforme o autor e a autora, no campo das representações, os céus eram coloridos de dourado, branco, vermelho ou preto.
} 


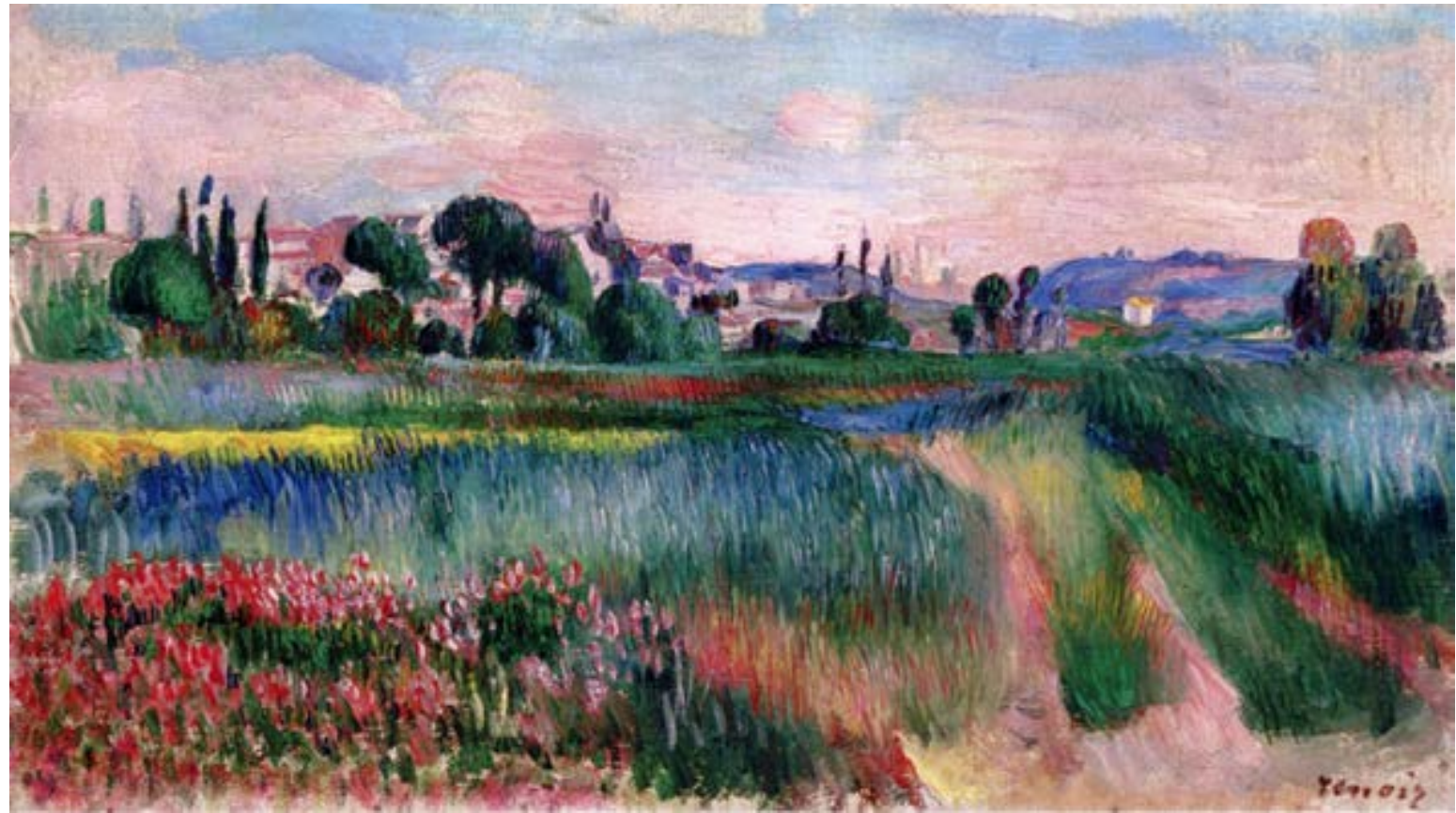

FONTE: 360 MERIDIANOS (2019); ARTVALUE (2019).

Diante da suposta fuga dos lápis azuis e da insatisfação que expressaram, assim como das três obras impressionistas que apresentamos à turma, propomos que os(as) alunos(as) desenhassem paisagens utilizando outras cores pra colorir o céu e o mar. Com isso, nossa intenção foi, não só ampliar o referencial visual e artístico das crianças, como também, conforme temos argumentado até aqui, problematizar e desestabilizar os usos estereotipados que até então vinham atribuindo às cores. A Figura 10 apresenta resultados dessa atividade e, analisando-os, percebemos que, assim como Monet e Renoir, as crianças de quatro e cinco anos conseguiram desvincular o céu da cor azul - ainda que momentaneamente - e atribuir a esse elemento comum as representações de paisagens, outras cores como verde, amarelo e roxo. Os dois desenhos que mostramos em nível de exemplificação atestam que algumas crianças adotaram outra cor, como o amarelo, para preencher não apenas o céu e o mar, mas também outros elementos de sua composição; e outras misturaram mais cores como amarelo, verde e marrom.

FIGURAS 10: DESENHOS DE DUAS MENNNAS, AMBAS COM CINCO ANOS.

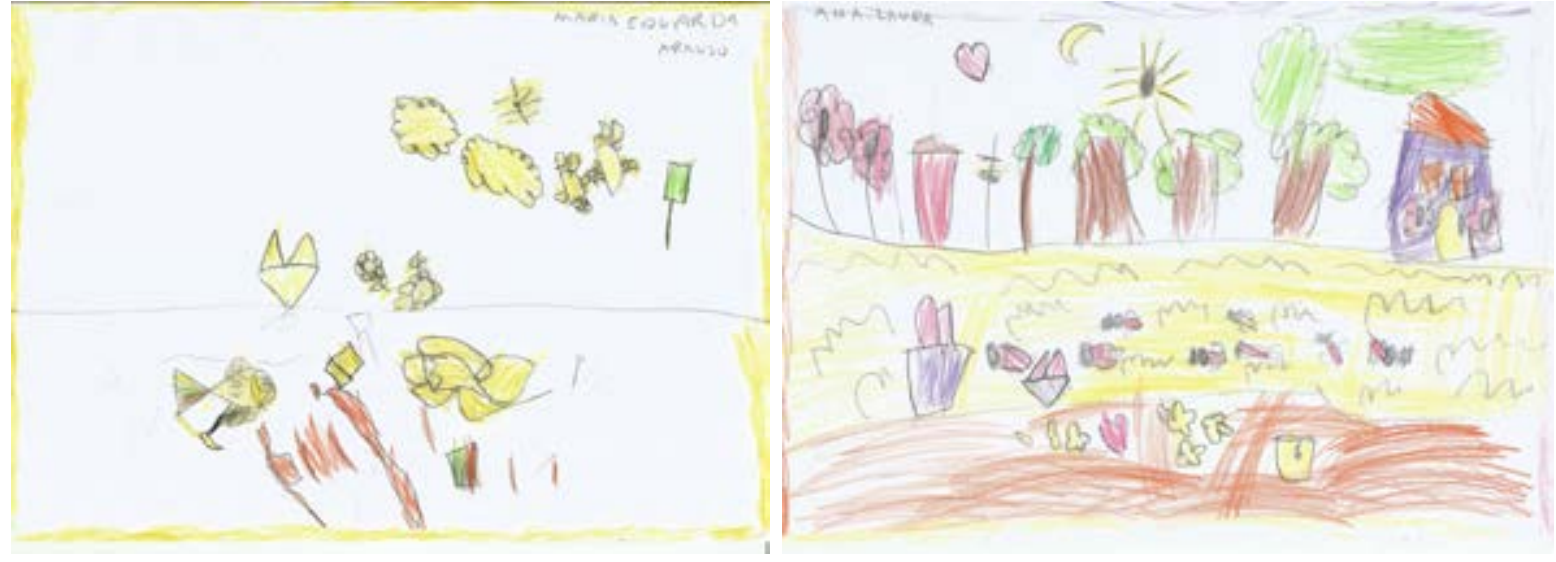

FONTE: ARQUIVO PESSOAL, २०16

Durante a realização da atividade avaliamos que, de certa forma, os(as) meninos(as) demonstraram resistência em colorir o céu, e, para atender a nossa solicitação de usar as cores de modos inusitados, 
optaram por colorir as nuvens. Esse dado, consideramos, revela uma característica comum entre os(as) alunos(as) dessa idade - que é empregar cor às nuvens e não ao espaço indicativo do céu - e aponta para a necessidade de docentes e familiares proporcionarem às crianças a percepção da configuração do céu. Um convite para olhar o céu da parte externa da escola ou para observar as maneiras como artistas representaram as nuvens em suas obras, por exemplo, são ações que poderiam, talvez, surtir efeito na maneira como as crianças percebem e pintam o céu. A água, por sua vez, diferente do céu, foi pintada pela maioria das crianças. O primeiro desenho da figura é um dos poucos em que as crianças repetiram, na água, a mesma aplicação cromática empregada no céu: não colorir o fundo. Ainda sobre esses desenhos onde as crianças fizeram uso pouco convencional das cores para identificar o céu e a água, identificamos que algumas estruturas cromáticas se mantiveram estereotipadas, como o telhado laranja, as pétalas de flores vermelhas, e as copas e troncos das árvores pintados, respectivamente, de verde e marrom. Essa percepção sugere, novamente, a necessidade de ampliação do repertório visual das crianças e do acesso à flores, troncos e folhas de outras cores que não as usuais.

Finalizada esta atividade, sugerimos que os(as) alunos(as) procurassem os lápis azuis fugitivos nos espaços externos do Centro Municipal de Educação Infantil. Divididas em dois grupos, as crianças procuraram pelos lápis ao mesmo tempo que apontávamos as cores dos elementos da natureza, como o azul do céu e o verde das árvores, sugerindo possíveis modificações cromáticas. Escondemos os lápis dentro de um pneu que cercava o caminho do parquinho. As crianças se dispersaram muito mais rápido do que imaginávamos, e por esse motivo, tivemos que conduzi-las até o local onde os lápis estavam escondidos e ajudá-las a procurá-los. Quando um dos alunos encontrou os lápis convidamos as demais crianças para se aproximarem, incentivando a ideia de união e trabalho em grupo.

Seguimos para a última atividade, mostrando-lhes mais três imagens de obras impressionistas, desta vez, porém de natureza morta e ambientes internos. Consideramos que essas pinturas contribuiriam para que as crianças criassem outros significados cromáticos para o azul e percebessem que essa cor poderia ser empregada na coloração de outros elementos para além do céu e do mar. Refletimos com as crianças: já que os lápis azuis haviam fugido por terem sido usados sempre das mesmas formas e para colorir céus, uma maneira interessante de recebê-los de volta seria procurar por imagens onde o azul fora empregado em outros elementos. Conforme apresentamos nas Figuras 11, 12 e 13, A praia em Trouville (1870), de Monet, Natureza morta com vaso azul (1887), de Cézanne, e Interior com um violino (1918), de Henri Matisse, a cor azul fora utilizada pelos impressionistas na representação de objetos, tais como guarda-chuva, vaso de flores e case de violino.

FIGURAS 11, 12 E 13: A PRAIA EM TROUVILLE(1870), DE CLAUDE MONET, NATUREZA MORTA COM VASO AZUL (1887), DE PAUL CÉZANNE, E INTERIOR COM UM VIOLINO(1918), DE HENRI MATISSE
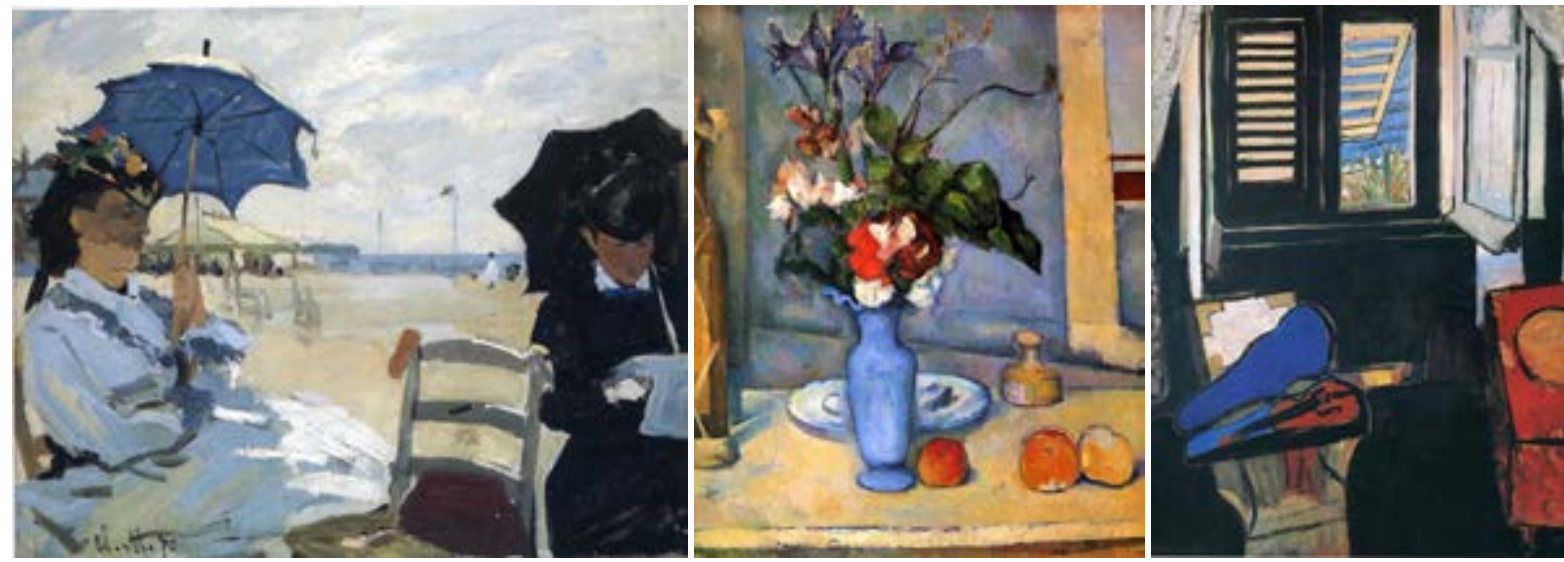

FONTE: ARTBLOG (2019); GENUÍNO INTERESSE (2019); MUSEO THYSSEN-BORNEMISZA (2019).

Como estratégia para que as crianças observassem esses objetos e demais detalhes das obras impressionistas, familiarizando-se com elas, entregamos-lhes uma folha com cinco representações de objetos: um guarda-chuva, um vaso de flores, uma cama, um case de violino e laranjas. Direcionamo-las para que observassem atentamente o último conjunto de obras apresentado e que, a partir disso, pintassem de azul 
em suas folhas individuais apenas aqueles objetos que foram representados de azul pelos impressionistas. A Figura 14 ilustra essa atividade. Observando-a, percebemos que uma criança alcançou o objetivo apresentado pelo enunciado da atividade, colorindo em azul apenas os objetos representados na mesma cor. Embora a aluna tenha colorido de azul apenas parte do case do violino - o que sugere atenção aos detalhes da obra de Matisse - ao colorir o vaso, acabou expandindo a tonalidade para as flores, o que não corresponde à aplicação feita por Cézanne na obra original. Além disso, observamos que a aluna coloriu a margem da folha espontaneamente - comportamento este que é repetido por outros(as) colegas, o que pode sinalizar que tal prática é comum nas aulas.

FIGURA 14: ATIVIDADE APLICADA ÀS ALUNASE ALUNOS.

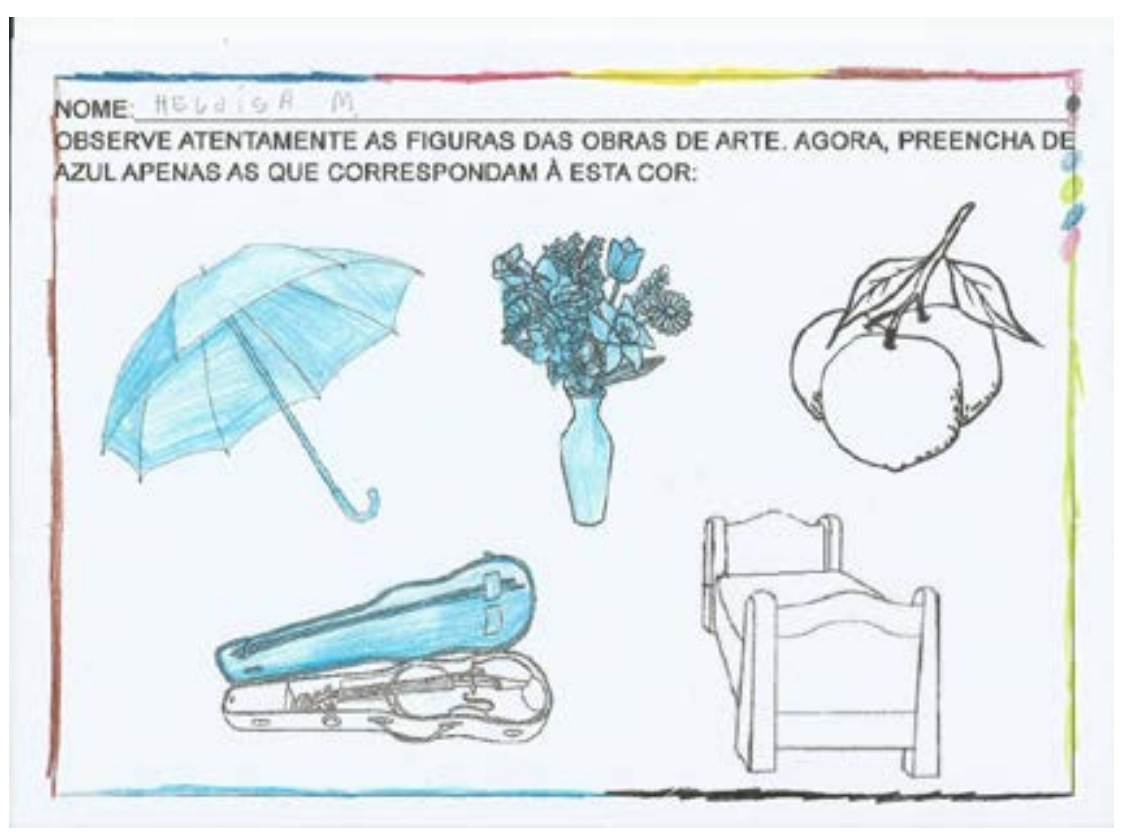

FONTE: ARQUIVO PESSOAL, 2016 .

Com este conjunto de intervenções, buscamos desenvolver movimentos para que as imagens populares às crianças, como aquelas de Os Smurfs, pudessem ser tomadas como disparadoras de análises sobre diferenças identitárias e, também, ser conectadas a produções da Arte. Por meio da cor azul - da pele de Os Smurfs e do céus e objetos representados pelos impressionistas - incentivamos as crianças a relacionarem elementos novos e já conhecidos com suas criações e interpretações visuais.

As atividades desenvolvidas nesse conjunto de regências remetem-nos a pelo menos três dos cinco Campos de Experiência ${ }^{5}$ que a BNCC recentemente instituiu para as intervenções pedagógicas na Educação Infantil. Consideramos que as atividades propostas por nós atenderam aos campos "O eu, o outro e o nós", "Corpo, gestos e movimentos" e "traços, sons, cores e formas", quando incentivamos as crianças a conhecer outras culturas, a perceber seu próprio corpo e a experimentar materiais artísticos, respectivamente. Além disso, harmonizam-se com a concepção que Cunha (2005) defende sobre o ensino de Artes Visuais na Educação Infantil.

[...] ampliar o repertório das imagens e objetos também implica abastecer as crianças de outros elementos produzidos em outros contextos e épocas, como, por exemplo, as imagens da história da arte, fotografias e vídeos, objetos artesanais produzidos por culturas diversas, brinquedos, adereços, vestimentas, utensílios domésticos, etc. (CUNHA, 2005, p. 14).

\footnotetext{
${ }^{5}$ Conforme a BNCC (2018) os Campos de Experiência são arranjos curriculares que promovem diálogos entre os conhecimentos trazidos pelas crianças e os conhecimentos compartilhados pela cultura na qual ela está inserida. Para além dos citados, os demais campos contemplados pelo documento são "Escuta, fala, pensamento e imaginação" e "espaços, tempos, quantidades, relações e transformações”.
} 
Considerando que as produções visuais - sejam elas artísticas ou não - estão ligadas ao contexto cultural, religioso, político e social de cada indivíduo, potencializamos imagens do universo infantil e da Arte a fim de expandir o repertório das crianças. Conforme demonstramos neste relato, com a mediação docente, os alunos e alunas foram capazes não só de aproximar as figuras apresentadas - ainda que em sua origem pertencessem a contextos temporais, geográficos e artísticos distintos - como também estabelecer diferentes significados para a cor azul.

\section{CONSIDERACÕES FINAIS}

O Estágio de Docência em Artes Visuais permitiu-nos, enquanto orientador e graduada de um curso de licenciatura, articular conteúdos estudados e impulsionou-nos na percepção de nossa própria identidade docente, sendo a nossa primeira experiência desenvolvida na Educação Infantil com crianças de quatro e cinco anos de idade. As regências que realizamos, em que os personagens de Os Smurfs foram aproximados de artistas e pinturas impressionistas, tendo a cor azul como eixo afinidade, confirmaram a potencialidade que o ensino de Artes Visuais tem para a formação de sujeitos intérpretes e críticos das visualidades de seu cotidiano.

Consideramos que, no geral, as crianças responderam positivamente às atividades, e conforme aplicávamos cada prática, elas demonstravam mais interesse e entusiasmo. Consideramos que tais resultados só foram possíveis a partir das observações que realizamos no Centro Municipal de Educação Infantil, momento no qual pudemos acompanhar não só a rotina da escola, as intervenções da professora, mas também cada criança e suas particularidades. Apesar do fato de nossa experiência ter sido exitosa, é preciso esclarecer que esse artigo, escrito como um relato de experiência, não tem como intuito apresentar uma fórmula ou modelo de estrutura de Estágio de Docência e muito menos de prática de ensino de Artes Visuais na Educação Infantil. Cada cidade, escola, turma, faixa etária e aluno(a) possuem suas próprias potencialidades e limites. Ainda assim, em um intuito de síntese e respaldados nos Estudos da Cultura Visual, nas considerações finais desse artigo, arriscamos a levantar dois pressupostos teórico-metodológicos que consideramos interessantes para pensar o ensino de Artes Visuais na Educação Infantil.

Primeiro, estabelecer articulações entre imagens populares, as crianças e as imagens da Arte: aproximar Os Smurfs das produções e artistas impressionistas pareceu-nos profícuo, pois, além de oportunizar debates e problematizações acerca dos corpos, gêneros e identidades intrínsecas às visualidades do cotidiano das crianças, estabeleceu relações afetivas entre elas e os impressionistas - o que, possivelmente, acarretou significações distintas daquelas possibilitadas pelas maneiras convencionais de apresentar artista/estilo artístico à uma turma. Além disso, consideramos que, pelas especificidades que envolvem os alunos e alunas da Educação Infantil, faz-se necessário criar estratégias para aproximar artistas (que muitas vezes habitaram outros contextos geográficos, culturais e temporais) com o contexto real da criança.

Segundo, desenvolver situações de ensino e recursos didáticos com base em brincadeiras: durante as observações que realizamos no Centro de Educação Infantil, chamou-nos a atenção a dificuldade que as crianças manifestavam por atender a comandos e orientações que, de imediato, não lhe provocavam satisfação. Esperar a vez de falar; ficar sentado(a) e em silêncio, por exemplo, pareceu-nos ações que nem todas as crianças conseguiam desempenhar, ainda que a professora justificasse a importância disso. Por outro lado, supomos que se pedíssemos para que as crianças ficassem sentadas ou até mesmo em silêncio para que "ouvissem o som que a turma do lado provocava" ou ainda "para que enganassem quem está no corredor, fingindo que a sala está vazia", tais orientações poderiam ser atendidas. Disso sublinhamos que a brincadeira é capaz de conduzir a situações de ensino, tal como experimentamos forjando a "fuga dos lápis azuis". Se não tivéssemos escondido os lápis e, ao invés disso, orientado às crianças para que produzissem desenhos sem a cor azul é possível que nossa solicitação não teria sido atendida. Ainda sobre esse pressuposto, é preciso destacar a criação e elaboração de recursos didáticos que fortaleçam a sensação de brincadeira e que envolvam as crianças nas atividades propostas. A carta - escrita por nós e supostamente deixada pelos lápis azuis - por exemplo, atuou como um reforçador da história inventada convidando as crianças a participarem do exercício-brincadeira. 
Dadas as condições do Estágio de Docência, o acompanhamento do(a) professor(a) orientador(a) e o tempo que tínhamos para elaborar as atividades de regência, não nos foi custoso estabelecer articulações entre imagens populares às crianças e imagens da Arte e tampouco desenvolver situações de ensino e recursos didáticos com base em brincadeiras. Contudo, sabemos, a realidade de professores(as) em exercício na Educação Infantil é diferente desta e é nesse sentido que chamamos a atenção do Estágio de Docência como uma oportunidade de troca, atualizações e identificações entre profissionais e acadêmicos(as) da área da educação. A aprovação de nossa proposta por parte da professora regente foi recebida por nós com alegria, sobretudo, por percebermos que ela estava disposta a utilizar algumas de nossas atividades em planejamentos futuros.

\section{REFEREENCIAS}

ARTBLOG, http://www.arteeblog.com/2016/09/a-historia-da-pintura-beach-at.html, Acesso em 28 de mai. De 2019.

ARTE Famoso. Disponível em: https://www.artefamoso.com/cuadros-de-cezanne/452-El-Sena-enBercy-de-Cezanne.html. Acesso em 28 maio 2019.

ARTVALUE. Disponível em: http://www.artvalue.com/auctionresult--renoir-pierre-auguste-1841-191paysage-2149855.htm. Acesso em: 29 maio 2019.

BOLLOCH, Joelle et al. Museu d'Orsay: guia de visitas. Paris: Éditions Artlys, 2012. 128p.

BRASIL. Ministério da Educação. Secretaria de Educação Básica. Base Nacional Comum Curricular. Brasília: MEC, 2018. Disponível em: http://basenacionalcomum.mec.gov.br/a-base. Acesso em: 20 out. 2019.

CUNHA, Susana Rangel Vieira da. Pintando, bordando, rasgando, desenhando e melecando na educação infantil. In: CUNHA, Susana Rangel Vieira da (org.). Cor, som, movimento: a expressão plástica, musical e dramática no cotidiano das crianças. 5. ed. Porto Alegre: Ed. Mediação, 2005. p. 7-36.

CUNHA, Susana Rangel Vieira da. Imagens na educação infantil como pedagogias culturais. In: MARTINS, Raimundo; TOURINHO, Irene (org.). Pedagogias culturais. Santa Maria: Ed. da UFSM, 2014. p. 199-224.

CUNHA, Susana Rangel Vieira da. Uma arte do nosso tempo para as crianças de hoje. In: CUNHA, Susana Rangel Vieira da; CARVALHO, Rodrigo Saballa de (org.). Arte contemporânea e educação infantil: crianças observando, descobrindo e criando. Porto Alegre: Mediação, 2017. p. 9-25.

GENUÍNO INTERESSE, http://rhistoriandoz.blogspot.com/2015/07/obras-imortais.html. Acesso em 28 de mai. De 2019.

HERNÁNDEZ, Fernando. Catadores da cultura visual: transformando fragmentos em nova narrativa educacional. Tradução de Ana Duarte. Porto Alegre: Mediação, 2007.

IAVELBER, Rosa. Desenho na educação infantil. São Paulo: Editora Melhoramentos, 2013.

LAMPERT, Jociele. Estágio supervisionado: andarilhando no caminho das Artes Visuais. In: HERNÁNDEZ, Fernando; OLIVEIRA, Marilda Oliveira de (org.). A formação do professor e o ensino das artes visuais. Santa Maria: Editora UFSM, 2005. p. 147-157.

MUSEO THYSSEN-BORNEMISZA, http://www2.museothyssen.org/microsites/exposiciones/2009/ Matisse/museo/museo1.html. Acesso em 28 de mai. De 2019.

NUNES, Luciana Borre. As imagens que invadem as salas de aula: reflexões sobre cultura visual. São Paulo: Ideias \& Letras, 2010.

NUNES, Luciana Borre; MARTINS, Raimundo. Cultura visual tramando gênero e sexualidades nas escolas. Recife: Editora UFPE, 2017. Disponível em: https://issuu.com/lucianaborre/docs/cultura_ visual_tramando_genero_e_se. Acesso em: 10 setembro 2019. 
OLIVEIRA, Marilda Oliveira de. A formação do professor e o ensino das artes visuais: o estágio curricular como campo do conhecimento. In: Hernández, Fernando; OLIVEIRA, Marilda Oliveira de (org.). A formação do professor e o ensino das artes visuais. Santa Maria: Editora UFSM, 2005. p. 57-72.

PASTOUREAU, Michel; SIMONNET, Dominique. Breve historia de los colores. Barcelona: Ediciones Paidós Ibérica, 2006.

PORTAL da Arte. Disponível em: https://www.portaldearte.com.br/product-page/monet-a-caminhadado-penhasco-em-pourville. Acesso em 28 de mai. de 2019.

SARDELICH, Maria Emília. Leitura de imagens, Cultura Visual e prática educativa. Cadernos de Pesquisa, São Luís, v. 36, n. 128, p. 451-472, maio/ago., 2006. Disponível em http://www.scielo.br/pdf/ cp/v36n128/v36n128a09.pdf. Acesso em 10 de set. de 2019.

SMURFS, wiki. Disponível em: https://smurfs.fandom.com/wiki. Acesso em 28 de mai. de 2019.

UEM. Resolução 061/2010-CI/CCH - Aprova o projeto pedagógico do Curso de Graduação em Artes Visuais: regulamento do componente estágio curricular supervisionado do curso de Artes Visuais - licenciatura modalidade presencial. Maringá, 2010. Disponível em: http://www.cch.uem.br/ resolucoes_10/061_10.pdf. Acesso em de 10 set. 2019.

WIKIART: Visual Art Encyclopedia. Disponível em: https://www.wikiart.org/en/claude-monet/redboats-argenteuil-1875-oil-on-canvas-1875. Acesso em 28 de mai. de 2019.

360 MEREDIANOS. Disponível em: https://www.360meridianos.com/especial/as-viagensimpressionistas-de-monet. Acesso em 29 de mai. de 2019. 